\title{
A Study on the Construction of English Curriculum System for ELE and ESP Universities in Provincial Universities
}

\author{
Weina Ouyang ${ }^{1}$ and Dan $\mathrm{Li}^{1, *}$ \\ (Foreign Language Education Institute, Beihua University of Jilin 132000, China)
}

\section{Keywords: ELE; ESP; English Curriculum System; Provincial Universities}

\begin{abstract}
Domestic ELE and ESP research and application has always been affected by foreign research, to the application of personnel training-oriented ELE and ESP curriculum system construction of Chinese studies, especially the provincial colleges and universities is not sufficient, the provincial college English teaching education Therefore, it is very important to study and practice the college English curriculum system oriented by the applied talents in the provincial colleges and universities at the level of the provincial colleges and universities. This essay promotes the further development of college English teaching reform, strengthen the training of students' autonomous learning ability and innovation ability, and improve the quality of college English teaching in our province and cultivate high-quality talents with strong English ability. The practical significance of the province to promote college English teaching reform has a certain guiding significance.
\end{abstract}

\section{Introduction}

The Status of Foreign Research. ELE (English for Liberal Education) refers to the English curriculum for general education, that is, through language education to improve the overall quality of learners. Many well-known foreign universities attach importance to general education, such as the United States Harvard, Yale and other universities set up a number of general education courses.

ESP (Language for Specific Purpose) refers to the concept of specialized language, is a teaching philosophy, its teaching content and methods are dependent on the student's learning motivation (Hutchinson, Waters, 1987). ESP is a course designed to meet students' motivation and professional needs. In recent years, with the development of ESP, more and more colleges and universities in public English teaching are based on ESP education.

The Status of Domestic Research. The general education in foreign language teaching in our country was originally proposed for the cultivation of foreign language students. The gradual expansion of the university foreign language education to the generalization of the shift relies on general courses for college foreign language teaching. College English teaching is to cultivate students' humanistic quality, and to educate students on general education.

China began to introduce ESP teaching in the 1980s, getting more and more colleges and universities of the positive response and theoretically discussed. Scholars to promote higher education should be used for special purpose English teaching, in order to change the English teaching in China a serious problem of teaching tendencies.

Application-oriented personnel training policy guidance and research in 2007, the Ministry of Education pointed out that undergraduate level application of innovative talents should be different from the academic research, skilled personnel training. The corresponding implementation of the initiatives and requirements, the basic action strategy has not yet formed the requirements, testing and evaluation of a serious lack of content. Therefore, the application of talent training college English curriculum system we need to conduct in-depth study. 


\section{Construction of ELE and ESP Course System}

Teaching Purposes. According to the application of personnel training requirements to clear and develop teaching objectives, a clear outline and content, as well as to achieve the purpose of teaching. The goal of teaching is not only the concrete goal of personnel training, but also the teaching standard of course.

Improve the Construction of Teaching Materials. As the carrier of teaching content, should meet the learners in the learning base, learning objectives and learning interests and other requirements. Curriculum research from the perspective of the cultivation of applied talents, in the teaching of ELE and ESP teaching materials set according to the different professional teaching purposes, outline and content set. ELE teaching materials should be from the teaching theory and students at different levels of division and other aspects of consideration to set up. ESP teaching materials in addition to consider the above factors, but also from a better service to the students career planning as a prerequisite to practice, application-based settings.

In addition to the selection of existing teaching materials, according to social needs, professional needs and the different needs of students, different levels of teaching materials; can also be based on student level selection and processing of appropriate, consistent with the goal of authentic teaching materials, really related to corpus.

Teaching Model Research. In the ELE and ESP college English curriculum teaching method, in addition to try to student-centered teaching method, schema construction method, task teaching method, heuristic teaching method and other traditional teaching methods, but also should try to try multi-modal teaching Way, play the network resources and students' ability of independent learning and other important role, to develop a curriculum requirements and training objectives of the scientific teaching model.

Integrate Teaching Resources. The existing books of all kinds of books can be the basis of teaching resources, but also a lot of reference and use of network information, $\mathrm{Mu}$ classes, micro courses, according to the characteristics of multi-mode textbooks, make full use of pictures, text, audio , Video and online links and other teaching resources. At the same time with the school of various types of simulation teaching resources, in college English classroom teaching can also take into account the physical display, workplace simulation, simulation training, etc., many aspects of integration of various teaching resources.

Teachers' Ability Training. First of all, from the curriculum system for the requirements of teachers to start, put forward the level of teachers' knowledge reserves and practical teaching ability requirements. Secondly, from the teacher's mind to start, change the traditional concept of teachers, from the theoretical to the combination of theoretical practice combined with the concept. Strengthen the teacher training, according to the curriculum requirements for teacher training recommendations.

\section{Course Content and Method Construction}

Curriculum System Level Division. According to the requirements of "College English Teaching Requirements", the school should set up various compulsory courses and elective courses according to the actual situation, "to set up their own college English curriculum system", to ensure that students at different levels in the application of English ability to be sufficient Training and improvement ". How to classify students and set up a curriculum system that conforms to the student level has become an important part of the research. Can be divided according to the traditional according to the traditional level, according to the initial test level of admission, you can also try to professional division, such as basic disciplines, applied disciplines and other types, such as Chinese professional and mechanical professional use of different ELE and ESP course content.

ELE and ESP combined with CBI. CBI (Content-based Instruction) that the content of relying on teaching, language and discipline to guide together. Combined with the different teaching content of 
ELE and ESP course system, the theme of classification, based on teaching materials, teaching content to expand and extend, and ELE and ESP classroom and extracurricular self-learning task theme to keep pace. For the teaching of ELE and ESP advanced course content, it is necessary to strengthen the effectiveness of supervising students 'self-learning, and to strengthen students' learning ability through rich classroom activities to guide students to develop academic English application ability according to their professional needs.

Build Multi-modal Teaching Method. ELE and ESP-based college English curriculum system can be based on the original variety of teaching methods, in the classroom for multi-modal teaching practice research, such as simulation of academic forums, work environment simulation, etc. in teaching to be specialized, Career, real. In addition to classroom teaching to achieve multi-modal, extra-curricular students with multi-modal learning resources for self-learning, teachers use extra-curricular means of counseling

\section{Key issues in research}

The Construction of the Curriculum System. The development of college English curriculum quality evaluation system should be based on the curriculum standards, followed by domestic and foreign widely recognized foreign language education evaluation standards, such as teaching evaluation criteria, teaching quality evaluation standards, student English ability evaluation standards, teacher entry qualification standards, Construction should take full account of multi-factor.

The Application of Course System Construction in Practical Teaching. The practical effect of the curriculum system in classroom teaching, extracurricular teaching, autonomous learning and teacher counseling has become the key of the research. Through the application of ELE and ESP college English curriculum system in teaching practice, we can improve the problems in curriculum construction and further improve the construction of curriculum system.

The influence of Teachers' Professional Development on the Construction of Curriculum System. Teachers are the main body of teaching reform, whether ELE or ESP teacher ability is the primary factor in teaching reform. It is the key problem of curriculum construction that the "double teacher" teacher training can meet the requirements of teaching content of ELE course and the teaching content of ESP.

\section{Conclusion}

With the reform of basic education curriculum, the reform of college English teaching and education curriculum in our province is not balanced, and the effectiveness of college English curriculum reform has not yet been fully realized in some colleges and universities. Many of the institutions in general have a weak English foundation and a low overall English level. This project focuses on the English teaching of the "general requirement" level set by the "curriculum requirements", and focuses on the cultivation of the students 'comprehensive application ability in the way of ELE and ESP. It emphasizes the cultivation of students' cultural accomplishment and improves the overall English quality of college students, In line with the characteristics of quality education, is conducive to the completion of the application of personnel training. Through the study of the construction of college English curriculum system, the reform of college English curriculum content, methods and evaluation system is helpful to improve the teaching content, improve the teaching evaluation system, establish the curriculum system to cultivate the applied talents and realize the university English teaching from a single model to a variety of modes of change, so that our school English teaching a set of a variety of teaching methods and teaching methods as a whole, to English language knowledge and language practical skills, learning strategies and cultural literacy as the main teaching content integrity Scientific curriculum teaching system. 


\section{Acknowledgements}

2017 Major Project of Beihua University Teaching Reform, Research and Practice on the Construction of ELE and ESP University English Curriculum System in Provincial Colleges and Universities Based on the Cultivation of Practical Talents.

\section{References}

[1] F.Yang and L.Sun: Foreign Language Learning Theory and Practice, Vol. 3 (2013) No. 6, p.87.

[2] Robertblaker and Clairerkramschal. The Issue: National Language Educational Policy. The Modern Language Journal, Vol.2(2003)No.5, p.303

[3] B.Kumaravadivelu. A Postmethod Perspective on English Language Teaching.World English, Vol.4(2007)No.9, P26

[4] Sandra LeeMcKay. Toward an appropriate EIL pedagogy: Examining common ELE assumptions. International Journal of Applied Linguistics, Vol.3(2003)No. 8, p.125

About the author:

Ouyang Weina, female, born in 1980, lecturer in Public Foreign Language Education School of Beihua University, is mainly engaged in teaching methods, linguistics studies.

Li Dan, female, born in 1980, lecturer in Public Foreign Language Education School of Beihua University, is mainly engaged in translation, linguistics studies. 